\title{
Taphonomy and palaeoecology of mid-Cretaceous amber-preserved microorganisms from southwestern France
}

\author{
Vincent GIRARD \\ Université Rennes I, UMR CNRS 6118 Géosciences, \\ campus de Beaulieu bât. 15, 263 avenue du Général Leclerc, \\ F-35042 Rennes cedex (France) \\ vincent.girard@univ-rennes1.fr
}

Alexander R. SCHMIDT

Steffi STRUWE

Courant Research Centre Geobiology, Georg-August-Universität,

GöttingenGoldschmidtstraße 3, D-37077Göttingen (Germany) and Museum für Naturkunde der Humboldt-Universität zu Berlin, Invalidenstrasse 43, D-10115 Berlin (Germany)

Vincent PERRICHOT

Paleontological Institute, University of Kansas, Lindley Hall, 1475 Jayhawk blvd, Lawrence, KS 66045 (USA)

Gérard BRETON

Didier NÉRAUDEAU

Université Rennes I, UMR CNRS 6118 Géosciences, campus de Beaulieu bât. 15, 263 avenue du Général Leclerc, F-35042 Rennes cedex (France)

KEY WORDS

Palaeoecology, taphonomy, amber forests, microorganisms, Cretaceous, France.
Girard V., Schmidt A. R., Struwe S., Perrichot V., Breton G. \& Néraudeau D. 2009. - Taphonomy and palaeoecology of mid-Cretaceous amber-preserved microorganisms from southwestern France. Geodiversitas 31 (1): 153-162.

\begin{abstract}
The investigation of microorganisms preserved in amber from CharenteMaritime (southwestern France) provides new insights into the mid-Cretaceous amber forest ecology. Amber from the localities of Archingeay-Les Nouillers and Cadeuil is unique due to the plethora of microinclusions and macroinclusions as well as the preservation of litter organisms. Soil microorganisms such as actinomycetes, sheathed prokaryotes, carnivorous fungi (Ascomycota), algae, testate amoebae and nematodes indicate that the resin solidified in terrestrial or limnetic-terrestrial microhabitats on the forest floor. Furthermore, arboreal and even marine microorganisms are preserved in the amber. This micro-assemblage suggests that the amber forest was located close to the sea shore or was at least temporarily under marine influence.
\end{abstract}


MOTS CLÉS

Paléoécologie, taphonomie, forêts à ambre, micro-organismes, Crétacé, France.

\section{RÉSUMÉ}

Taphonomie et paléoécologie des microorganismes préservés dans l'ambre médiocrétacé du sud-ouest de la France.

L'investigation des micro-organismes préservés dans l'ambre de Charente-Maritime (sud-ouest de la France) fournit de nouveaux indices sur les écosystèmes forestiers à ambre médio-crétacés. L'ambre des localités d'Archingeay-Les Nouillers et de Cadeuil est unique par l'abondance de micro- et macro-inclusions ainsi que par la préservation d'organismes de litière. Des micro-organismes du sol tels que des actinomycètes, des procaryotes gainés, des champignons carnivores (ascomycètes), des algues, des amibes testées et des nématodes, indiquent que la résine s'est solidifiée dans des micro-habitats terrestres ou limniques-terrestres au niveau du sol de forêt. En outre, des micro-organismes arboricoles et même marins sont également préservés dans cet ambre. Ce micro-assemblage suggère que la forêt à ambre était située à proximité de la mer ou était au moins temporairement sous influence marine.

\section{INTRODUCTION}

Amber localities of southwestern France are known for a couple of hundred years (Fleuriau de Bellevue 1817; for more details, see Néraudeau et al. 2009 [this volume]). However, before its re-discovery in 1999 by Didier Néraudeau and his team (Néraudeau et al. 2002, 2008, 2009 [this volume]; Perrichot 2005), amber from these localities has never been extensively investigated. Nowadays, the amber deposits of the Charentes region are known for the plethora of arthropods they contain (Perrichot 2005). In addition, studies on the palaeobotany and depositional environment provided many palaeoecological details (Néraudeau et al. 2002, 2008; Perrichot 2005; Vullo 2007). Two particular localities, ArchingeayLes Nouillers and Cadeuil, provide new insights into the mid-Cretaceous terrestrial environments from Western Europe in terms of arthropod fauna, vertebrate fauna and flora (Perrichot 2005; Vullo 2007). Up to now, the large amount of amber collected in quarries of Archingeay-Les Nouillers and Cadeuil allowed the discovery of more than 1000 fossil arthropods including mainly dipterans and hymenopterans but also neuropterans, orthopterans, coleopterans, arachnids, and crustaceans (Perrichot 2004, 2005).
Though extensive studies have been launched in the last years on this arthropod fauna, only few works have been attempted on the microfossils preserved in this amber. Galippe (1920) mentioned the presence of microbes in amber from Enet Island (Charente-Maritime) and Berland (Charente). He noticed that some of the bacteria he found were able to develop on growth medium in the laboratory. This observation suggests that they were not fossil bacteria but merely contaminants of the amber. More recently Schlüter (1978) investigated amber from Enet and Aix islands but he failed to find any macro- or microinclusions. Breton \& Tostain (2005) and Breton (2007) mentioned that some sheathed prokaryotes found in Charentes amber look very similar to those described as Palaeocolteronema cenomanensis Breton \& Tostain, 2005 from the Cenomanian amber of Écommoy (northwestern France). Finally, Néraudeau et al. (2008) mentioned some cyanobacteria, bacteria and flagellate algae preserved in Cadeuil amber but without any detailed description.

Here we report palaeoecological implications based on the investigation of microinclusions of several highly fossiliferous pieces from Archingeay and Cadeuil which help to better understand the 
taphonomy and palaeoecology of microorganisms in their forested environments 100 million years ago.

\section{MATERIAL AND METHODS}

The amber containing the microcoenoses described here was collected from Late Albian layers of Archingeay-Les Nouillers and Cadeuil quarries. In both localities amber layers (from the lithological subunit A1; Néraudeau et al. 2002, 2008) are well developed within lignitic clay lenses that range from 0.1 to $1 \mathrm{~m}$ in thickness. This amber and the associated fossil wood were deposited in a coastal marine area, as indicated by the presence of oysters, teredinid bivalve holes in the wood, and marine foraminifera in the lignitic clay (Néraudeau et al. 2002; Perrichot 2005). More than $100 \mathrm{~kg}$ of amber were collected in these quarries so far. The present study describes the results obtained from highly fossiliferous pieces of two different kinds of amber. One has been described as litter amber by Perrichot (2004). It represents stratified amber pieces with dark layers at the bottom becoming more and more translucent from one side to the other. These amber pieces are exceptionally rich in arthropods. It is suggested that the resin flowed directly to the forest floor since many arthropods are litter-living inhabitants. The second kind is mainly composed of flattened pieces of dark red amber characterized by a greyish to whitish peripheral cortex composed of filamentous microorganisms (Girard et al. in press).

Several amber pieces had biofilms of modern microorganisms at their surface which were removed using ultrasonic cleaning and decontaminating baths, first in $9-10 \% \mathrm{H}_{2} \mathrm{O}_{2}$ then in $5 \% \mathrm{HF}$ as described by Girard et al. (2009a). Different techniques were used to investigate microorganisms:

- Very small and thin fragments of amber were removed from larger pieces using a minute scalpel and then mounted in Canada balsam or observed in water on a microscopic slide.

- Fragments containing arthropod inclusions were directly observed under the microscope in order not to destroy any fossils.
The amber pieces were investigated using highmagnification transmitted light microscopy (Leica DMLP, Nikon Optiphot).

The amber pieces investigated are deposited in the Muséum national d'Histoire naturelle, Paris and in the collection of the laboratory Géosciences Rennes (University Rennes I) (see figure legends for accession numbers).

\section{OBSERVED MICROCOENOSES}

Investigations of Archingeay-Les Nouillers and Cadeuil ambers revealed that microorganisms of at least three different habitats are preserved, since litter-dwelling, arboreal and marine organisms occur, sometimes together in a single piece of amber.

\section{LITTER-DWELLING AND SOIL-LIVING}

MICROORGANISMS

Most microorganisms found in this amber are litter- or soil-living taxa. Sheathed prokaryotes are the most abundant microinclusions. Most sheathed filaments are 6-10 $\mu \mathrm{m}$ in diameter (Fig. 1F) and are morphologically similar to the cyanobacterium Palaeocolteronema cenomanensis and to the sheathed bacterium Leptotrichites resinatus Schmidt \& Schäfer, 2005. These filiform inclusions sometimes form a 0.2 to $1.5 \mathrm{~cm}$ thick peripheral cortex in the amber pieces. Measurements of phycocyanin allow to prove that they correspond to P. cenomanensis (Girard et $a l$. in press). These prokaryotes grew in freshwater ponds or in wet soil on the forest floor.

Other abundant inclusions are short branched filament-forming actinomycetes. The filaments are of $c .1 \mu \mathrm{m}$ diameter and, at least two morphotypes are distinguishable. The most abundant, present in both outcrops, consists of filaments with dichotomous branching and forms microcolonies of up to $30 \mu \mathrm{m}$ diameter (Fig. 1A-C). No broken filaments have been found here and therefore we assume that they grew in the liquid resin. The other morphotype is characterised by filaments with perpendicular branching and associated spores (Fig. 1D, E).

Occasionally, also rod-shaped bacteria (Fig. 2G) and cyanobacterial filaments (Fig. 1G, H) were found. 

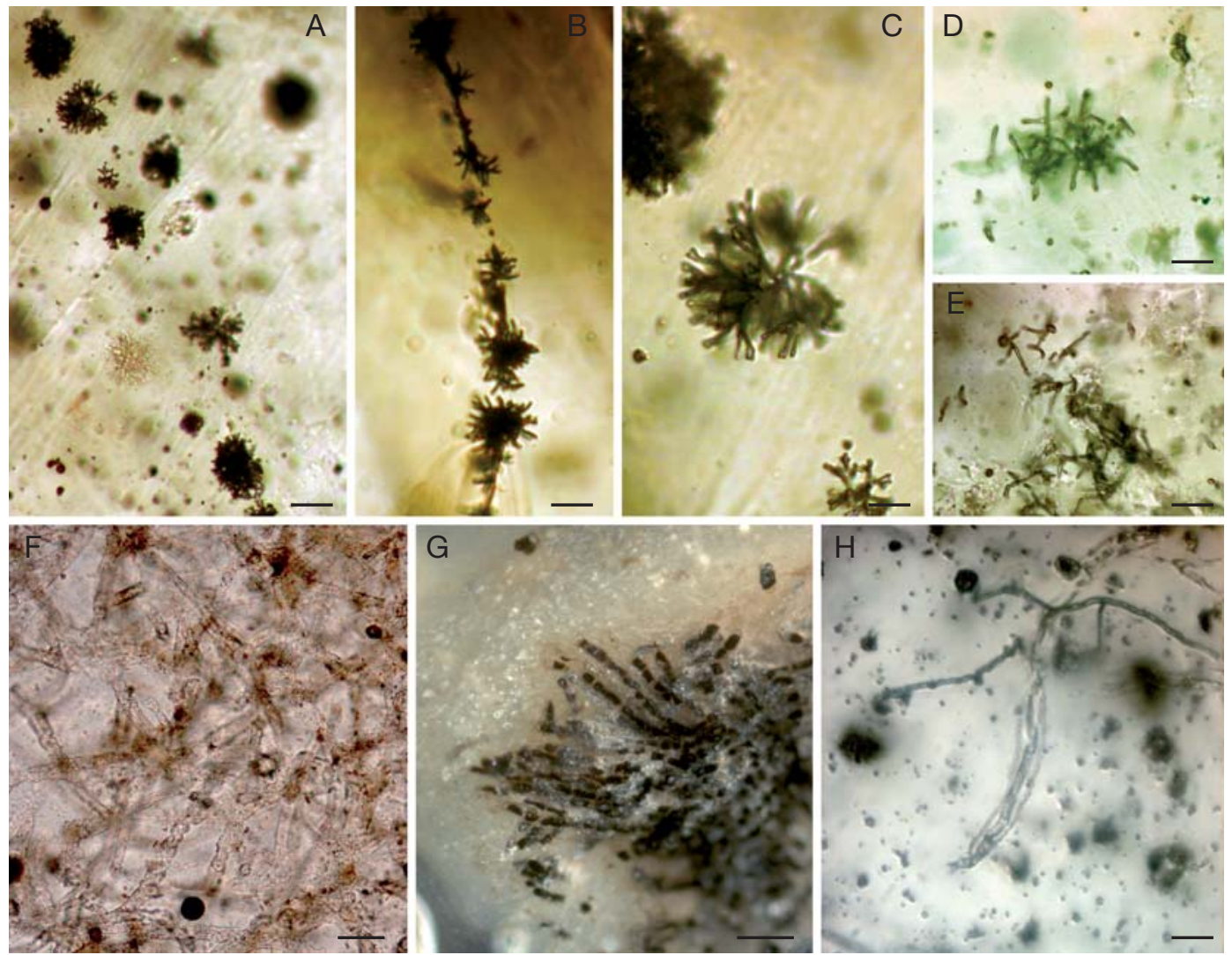

FIG. 1. - Prokaryotes found in Archingeay-Les Nouillers (ARC) and Cadeuil (CDL) ambers: A, B, microcolonies of actinomycetes with dichotomous branching; A, ARC115.22a; B, CDL2-107; C, detail of a single microcolony of Figure 1A (ARC115.22a); D, E, actinomycetes with perpendicular branching (ARC115.13a.2); F, sheathed filaments of cyanobacteria (ARC(1-1)C); $\mathbf{G}$, filaments of a possible big cyanobacterium (CDL9L-e6); H, sheathed cyanobacterium (ARC111). Scale bars: A, B, $20 \mu \mathrm{m} ; \mathrm{C}-\mathrm{E}, \mathrm{H}, 10 \mu \mathrm{m} ; \mathrm{F}, 30 \mu \mathrm{m} ; \mathrm{G}, 100 \mu \mathrm{m}$.

Diverse eukaryotes were found associated with these prokaryotes. Different occurrences of septate hyphae show the presence of Ascomycota and Basidiomycota (Fig. 2B). Some were preserved only as hyphae, and some other only as spores. Rare cases of fungal fossils exhibiting both hyphae and spores in connection have been observed, sometimes forming dense mycelia. A dimorphic fungus forming mycelia and yeast stages has been identified as a carnivorous fungus (Ascomycota) based on the occurrence of hyphal rings as trapping devices (Schmidt et al. 2007). Nematodes which were found close to this fungus can be considered as its potential prey.

Two taxa of freshwater green algae have been found. A three-celled alga similar to the modern genus Myrmecia Schreber, 1789 (Chlorococcales,
Chlorococcaceae; Fig. 2G) has been found associated with rod-shaped bacteria in Archingeay amber. Cadeuil amber provided a specimen of Enallax napoleoni Girard, 2009 (Chlorococcales, Scenedesmaceae; Girard 2009 [this volume]; Fig. 2H).

Few freshwater or soil-living testate amoebae and possible cysts of those have been found in Archingeay amber. One taxon is morphologically similar to modern specimens of Centropyxis discoides Ehrenberg, 1838 (Fig. 2I) and a second taxon to the rare modern Leptochlamys ampullaria West, 1901.

\section{ARBOREAL FUNGI AND PLANT REMNANTS}

Apart from numerous stellate and pennate hairs which probably originate from angiosperm trees of the amber forest, we found mycelia and single 

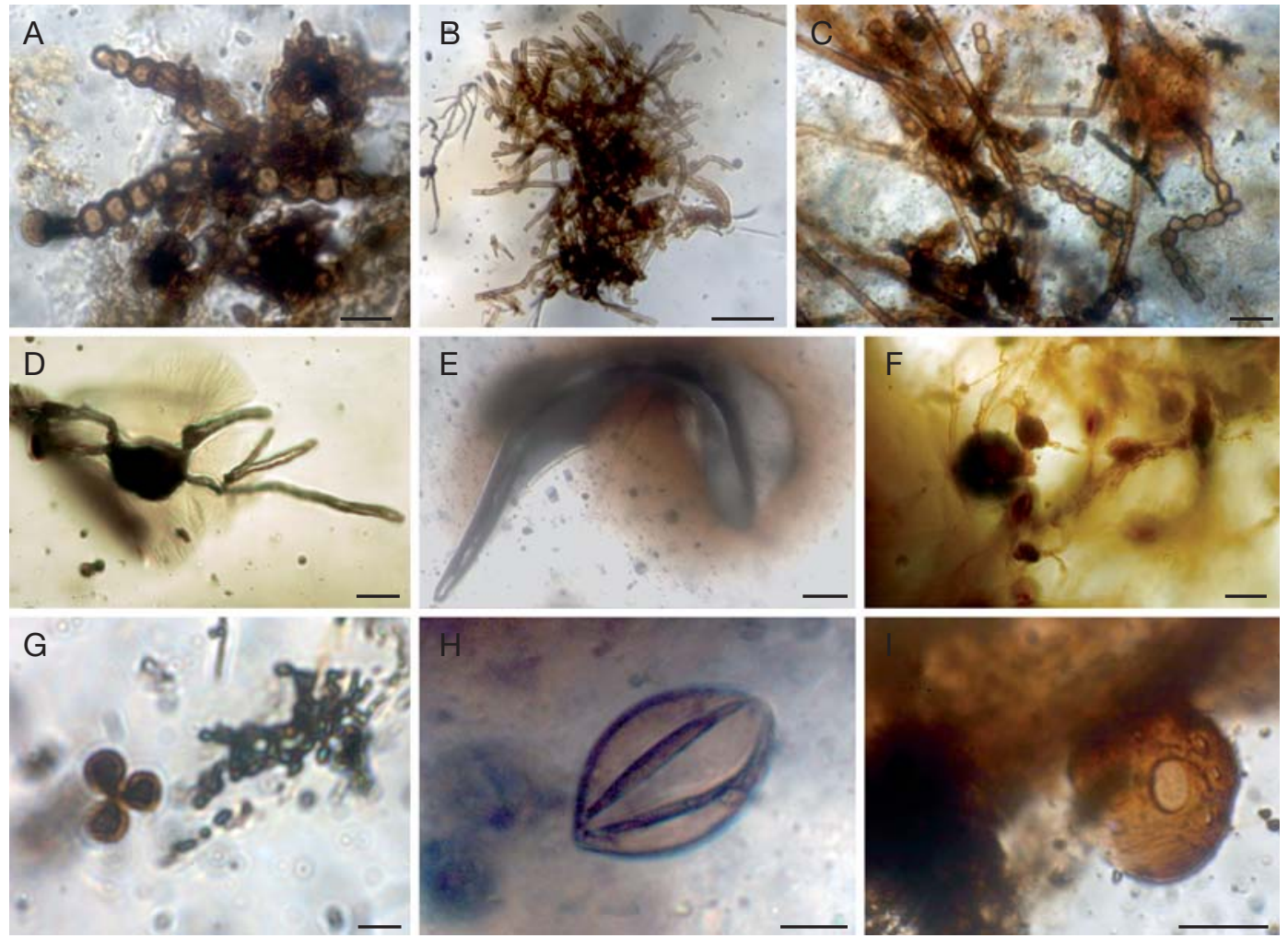

FIG. 2. - Selected eukaryotes found in Archingeay-Les Nouillers (ARC) and Cadeuil (CDL) ambers: A, aerial hyphae of a Metacapnodiaceae representative (ARC115.3); B, septate hyphae of ascomycetes or basidiomycetes (CDL2.31); C, septate hyphae forming arthrospores (ARC38M); D, germinating spore (CDL2-106); E, nematode (ARC149.7); F, fungal hyphae forming possible chlamydospores (CDL2-106); G, three-celled Myrmecia-like green alga (left) and rod-shaped bacteria (right) (ARC115.9); H, Enallax-like green alga (CDL26c); I, Centropyxis discoides-like testate amoeba (ARC115.21). Scale bars: A, $10 \mu \mathrm{m} ; \mathrm{B}, 30 \mu \mathrm{m} ; \mathrm{C}, \mathrm{H}, \mathrm{I}, 20 \mu \mathrm{m}$; $\mathrm{D}, \mathrm{F}, \mathrm{G}, 5 \mu \mathrm{m} ; \mathrm{E}, 50 \mu \mathrm{m}$.

hyphae of epiphytic fungi preserved in Archingeay amber. They represent the oldest known specimens of sooty moulds, an ecological group of ascomycetes which are specialized in inhabiting tree bark and twigs in humid environments. At a part of the mycelium some aerial hyphae (Fig. 2A) are preserved. The nearly globular shape of the hyphae and the ampullaceous apical dividing stages resemble those of the modern family Metacapnodiaceae. Fossils of sooty moulds were previously only known from Eocene Baltic and Oligocene Bitterfeld amber (Rikkinen et al. 2003).

Insect excrements are not rare in the mid-Cretaceous of southwestern France and they have largely been attributed to termites due to their general shape. Some faecal pellets from Cadeuil amber, however, might also provide evidence of arboreal fungi since they consist of septate hyphae. Peculiar setae and basidiospores found in Cadeuil amber provide evidence of the presence of polypores growing on the trees.

\section{MARINE MICROORGANISMS}

The most unusual discovery in the amber of Archingeay are marine microorganisms (Girard et al. 2008, 2009b). Diverse centric diatoms (Fig. 3A, $\mathrm{B}, \mathrm{D})$ and other siliceous shells have been found in several litter amber pieces sensu Perrichot (2004). Most diatoms have been found as inclusions of single cells but chains of two or three cells also occur. 

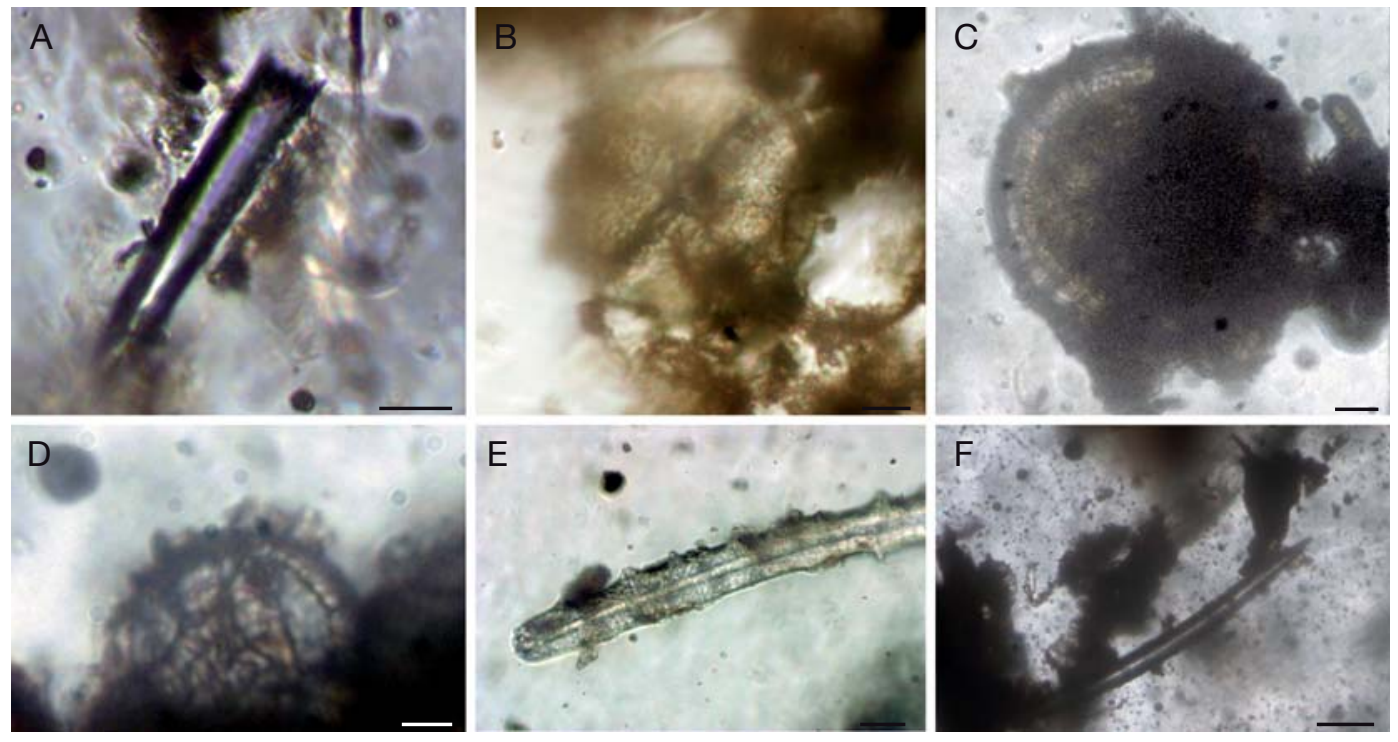

FIG. 3. - Selected marine microorganisms found in Archingeay-Les Nouillers (ARC) amber: A, filiform centric diatom with a ring of spines (ARC115.11); B, centric diatom (ARC115.22); C, possible radiolarian (ARC115.2); D, centric diatom partially hidden by detritus (ARC115.11r); E, sponge spicule with central canal and a spiny surface (ARC115.12c); F, sponge spicule (ARC226.27). Scale bars: A, C, E, $5 \mu \mathrm{m}$; B, D, $10 \mu \mathrm{m} ; \mathrm{F}, 50 \mu \mathrm{m}$.

Both morphological comparison to modern taxa and the known diatom fossil record suggest that these diatoms are marine (Girard et al. 2009b). The first occurrence of non-marine diatoms comes from the Maastrichtian of Mexico where an assemblage of both centric and pennate diatoms was found (Chacón-Baca et al. 2002). Further marine amber inclusions are monoaxone sponge spicules, probably of demosponges, occurring in the three different amber pieces from Archingeay-Les Nouillers (Fig. 3E, F) (Girard et al. 2008). A rounded siliceous inclusion, looking like a radiolarian, has also been found in a piece of litter amber (Fig. 3C).

\section{TERRESTRIAL MICROORGANISMS}

\section{OF UNKNOWN ORIGIN}

Four different kinds of nematodes have been found in Archingeay and Cadeuil amber (Fig. 2E). One was attributed to litter environments (see above) and three other were found in amber pieces that also contained both arthropods and plant debris. These associations in amber could be accidental and there is no direct evidence for any parasitism of these arthropods and plants by the nematodes. Whether they were trapped together with their host or independently on the forest floor or at a tree trunk is thus not determinable.

A well-preserved mycelium with hyphae forming arthrospores has been found in Archingeay amber (Fig. 2C). The hyphae are septate and composed of quadratic, elliptical and sub-spheroidal cells. This specimen has been found on a fragment of wood embedded in amber, suggesting that it was a fungus growing either on the tree or on a wood fragment on the forest floor. First interpretation shows that this fungus has similarities with some modern representatives of the Pleosporales (Ascomycota) with spores resembling those of Valsaria insitiva Ces. \& De Not.

The prokaryotic inclusion shown in Figure $1 \mathrm{G}$ was found in the central part of an amber piece of Cadeuil, associated with wood debris and other sheathed prokaryotes. The cells appear to have a dark content and their shape and the growth form of the sheathed filaments suggest a cyanobacterial nature of the inclusion. 

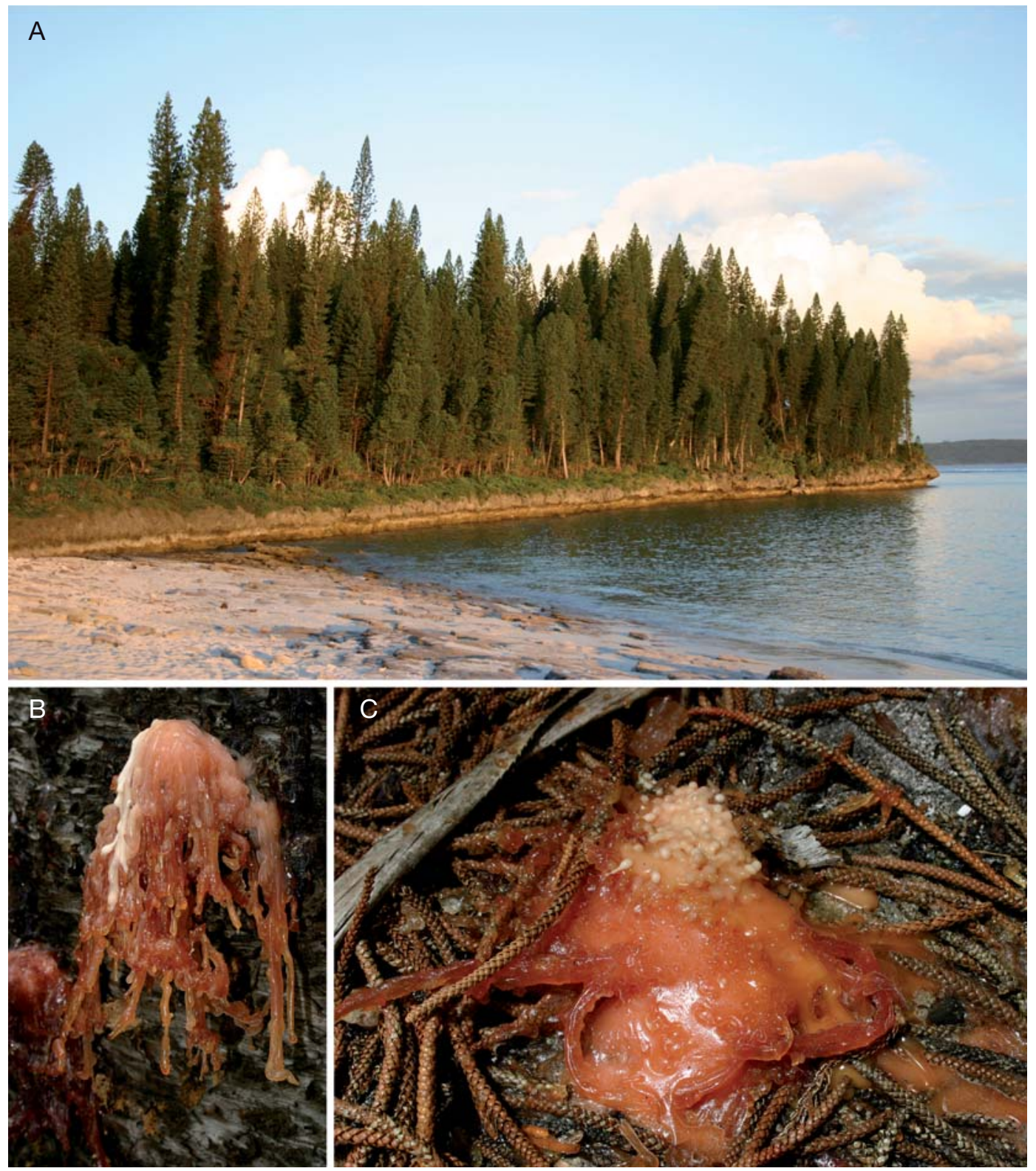

FIG. 4. - Resinous forest of New Caledonia as a possible analogue to the Cretaceous amber forests of southwestern France: A, resinous forest of Araucaria columnaris (J.R.Forst.) Hook. growing directly at the coast of Maré, New Caledonia. The sea appears very calm because the island is protected by a coral reef; $\mathbf{B}$, resin flow on the bark of $A$. columnaris; $\mathbf{C}$, resin dropping onto the forest floor, a possible future piece of litter amber.

In the same locality, hyphae forming possible chlamydospores (Fig. 2F) have been found associated with remains of an undetermined arthropod.
It was not possible to estimate where this fungal inclusion was embedded in the resin (on the forest floor or on the tree bark?). 
Several germinating spores (Fig. 2D) were found in Archingeay-Les Nouillers and Cadeuil amber. Without any diagnostic features, it was not possible to attribute them to any group of fungi.

\section{TAPHONOMY, PALAEOECOLOGY AND PALAEOENVIRONMENT}

The taphocoenoses preserved in amber from Archingeay-Les Nouillers and Cadeuil show influences of both forest and marine habitats. The forestal representatives are dominated by litter and soil microorganisms, especially by sheathed prokaryotes whose presence suggests that a large quantity of resin was produced in humid environments, similar to modern coastal Taxodium swamps in Florida (Schmidt \& Dilcher 2007).

The diverse assemblage of soil and litter microorganisms (including cyanobacteria, bacteria, actinomycetes, fungi, algae and testate amoebae) supports results previously obtained by the analysis of the arthropod fauna of Archingeay and Cadeuil amber. Perrichot $(2004,2005)$ introduced the term "litter amber" for pieces containing diverse litterdwelling arthropods. Two thirds of the arthropods preserved in litter amber are dipterans; half of them are characteristic for litter habitats. Among the other arthropods preserved, around 17\% (including homopterans, heteropterans, springtails and isopods) are also typical litter-living organisms. The occurrence of actinomycetes and soil fungi in these litter amber pieces confirms that particular resin pieces did not solidify on the tree bark, but on the forest floor.

The occasional occurrence of arboreal taxa, such as epiphytic fungi of the sooty moulds (Metacapnodiaceae) and plant remnants of stellate and pennate hairs, show that some of these particular pieces of resin were aerially secreted before solidifying on the forest floor. Thus, resin dropping on the ground from the tree trunks (Fig. 4B, C) or resin produced by superficial roots can be assumed.

Forest and marine microorganisms are not prone to be found as syninclusions in a single piece of amber and show that the amber forests were directly influenced by the marine environment (Girard et al.
2008). Sedimentological and palaeontological data indicate that an estuarine area under warm and wet climate existed in the Charentes region during the mid-Cretaceous. Analyses of the arthropod inclusions as well as the wood flora associated with amber also support an estuarine to mangrove-like environment (Perrichot 2005; Perrichot et al. 2007).

\section{AN ACTUALISTIC VIEW}

Today it is hard to find resinous conifer forests close to coastal estuarine environments. But a view into the extensive Araucaria forests along the coast of New Caledonia may help to comprehend the Charentes amber forest palaeoenvironment. Trees of Araucaria columnaris (J.R.Forst.) Hook. are often found standing directly at the sea shore on the rocks of coral limestone (Fig. 4A). Since the New Caledonian coast is protected by a coral reef, even dense forests of tall trees may grow in a coastal environment. Damage by fallen trees or branches, or fire may induce very extensive resin flow at the tree trunks (Fig. 4B). Resin drops or, when produced at the base of tree trunks or by roots, flows at the forest floor (Fig. 4B, C). These resin flows then covers the litter horizon.

Soil and litter-living organisms may become attached to and enclosed by the resin flows. Bacteria and fungi are often seen growing into resin as long as it stays liquid (Schmidt \& Dilcher 2007) and may therefore become secondarily accumulated. Organisms or parts of those fallen from the trees might become embedded at the upper side of the resin pieces. Marine taxa or their shells might also get in contact with resin when blown by the wind or spray at the resin bodies, or when previously introduced into the forest by high tides or storms before the resin flow occurred.

\section{CONCLUSION}

Palaeoenvironments are often reconstructed without any data about microfauna and microflora, the oldest organisms on earth and most important part of modern ecosystems in term of diversity and abundance. This important bias is mainly due to differential fossilization. Amber offers a unique 
way to access fossil microorganism assemblages. Archingeay-Les Nouillers (Late Albian) and Cadeuil (Late Albian-Early Cenomanian) ambers provides a new window into this past micro-world. It reveals that, during the mid-Cretaceous, amber forests grew in coastal position in the Charentes region. These amber forests had complex and diverse soil biocoenoses composed of cyanobacteria, bacteria, fungi, algae and testate amoebae. While arthropods preserved in these ambers are largely archaic representatives, many microbes from the Cretaceous forest floor are morphologically close to modern species. Probably their microhabitats and their roles in the food web changed so little in Earth's history that morphological changes were unnecessary.

One of the main characteristics of Archingeay and Cadeuil amber is that different microcoenoses are preserved, sometimes in the same amber piece. Interpreting the taphocoenosis of a single piece of amber, one has to consider that the organisms may originate from very different habitats, although captured in the same taphotope. Archingeay-Les Nouillers amber provides the best evidence for this.

\section{Acknowledgements}

We thank Simona and Jean-Paul Saint Martin (Muséum national d'Histoire naturelle, Paris), Heinrich Dörfelt (Institut für Geobotanik und Botanischer Garten, Halle) and Wilfried Schönborn (Institut für Ökologie, Jena) for their help in the determination of some inclusions. We also thank Kerstin Schmidt (Jena) and Saskia Jancke (Museum für Naturkunde, Berlin) for improving the English of the manuscript. Jérôme Munzinger (Institut de Recherche pour le Développement, Nouméa) contributed by his knowledge of suitable sampling sites in New Caledonia. The field studies in New Caledonia were kindly permitted by the Direction du développement économique et de l'environnement (Province nord) and by the Direction des Ressources naturelles (Province sud). The work on resin-preserved microorganisms is supported by the German Research Foundation (DFG) and by the Alexander von Humboldt Foundation. This article is a contribution to projects IFB Global Change
"Interactions biodiversité végétale - changements globaux à la transition Crétacé inférieur-supérieur d'Europe occidentale" and to the projet AMBRACE no. BLAN07-1-184190 from the Agence nationale de la Recherche (ANR).

\section{REFERENCES}

Breton G. 2007. — La bioaccumulation de microorganismes dans l'ambre: analyse comparée d'un ambre cénomanien et d'un ambre sparnacien, et de leurs tapis algaires et bactériens. Comptes Rendus Palevol 6: 125-133.

Breton G. \& TOSTAIN F. 2005. — Les microorganismes de l'ambre cénomanien d'Écommoy (Sarthe, France). Comptes Rendus Palevol 4: 31-46.

Chacón-Baca E., Beraldi-Campesi H., CevallosFerriz S. R. S., KNOLl A. H. \& GolubiC S. 2002. $70 \mathrm{Ma}$ nonmarine diatoms from northern Mexico. Geology 30: 279-281.

Fleuriau de Bellevue L. B. 1817. — Carte de l'île d'Aix, de l'île d'Enet et de Fouras. Archives de la Société des Sciences naturelles de Charente-Maritime 458 (fonds Fleuriau).

GALIPPE V. 1920. - Recherches sur la résistance des microzymas à l'action du temps et sur leur survivance dans l'ambre. Comptes Rendus de l'Académie des Sciences, Paris 170: 856-858.

GIRARD V. 2009. — Evidence of Scenedesmaceae (Chlorophyta) from 100 million-year-old amber. Geodiversitas 31 (1): 145-151.

Girard V., Schmidt A. R., Saint Martin S., Struwe S., Perrichot V., SAint Martin J.-P., Breton G. \& NÉrAUdEAU D. 2008. — Evidence for marine microfossils from amber. Proceedings of the National Academy of Sciences of the USA 105 (45):17426-17429.

Girard V., NÉraudeau D., Breton G., SAint Martin S. \& SAInT MarTin J.-P. 2009a. - Contamination of amber samples by recent microorganisms and remediation evidenced by mid-Cretaceous amber of France. Geomicrobiology Journal 26 (1): 21-30.

Girard V., Saint Martin S., Saint Martin J.-P., Schmidt A. R., Struwe S., Perrichot V., Breton G. \& Néraudeau D. 2009b. - Exceptional preservation of marine diatoms in Upper Albian amber. Geology 37 (1): 83-86.

Girard V., Breton G., Brient L. \& Néraudeau D. in press. - Sheathed prokaryotic filaments, major components of mid-Cretaceous French amber microcoenoses. Journal of Paleolimnology: doi 10.1007/ s10933-008-9287-2.

Néraudeau D., Perrichot V., Dejax J., Masure E., Nel A., Philippe M., Moreau P., Guillocheau F. \& 
GUYOT T. 2002. - Un nouveau gisement à ambre insectifère et à végétaux (Albien terminal probable) : Archingeay (Charente-Maritime, France). Geobios 35: 233-240.

Néraudeau D., Perrichot V., Colin J.-P., Girard V., Gomez B., Guillocheau F., Masure E., Peyrot D., Tostain F., Videt B. \& Vullo R. 2008. - A new amber deposit from the Cretaceous (Upper AlbianLower Cenomanian) of SW France. Cretaceous Research 29 (5-6): 925-929.

Néraudeau D., Vullo R., Gomez B., Girard V., LaK M., Videt B., Depré E. \& Perrichot V. 2009. Amber, plant and vertebrate fossils from the Lower Cenomanian paralic facies of Aix Island (CharenteMaritime, SW France). Geodiversitas 31 (1): 13-28.

Perrichot V. 2004. - Early Cretaceous amber from south-western France: insight into the Mesozoic litter fauna. Geologica Acta 2: 9-22.

PERRICHOT V. 2005. - Environnements paraliques à ambre et à végétaux du Crétacé nord-aquitain (Charentes, Sud-Ouest de la France). Mémoires de Géosciences Rennes 118: 1-310.

Perrichot V., Nel A. \& Néraudeau D. 2007. — Schizo- pterid bugs (Insecta: Heteroptera) in mid-Cretaceous ambers from France and Myanmar (Burma). Palaeontology 50: 1367-1374.

RikKinen J., DÖRfELt H., SCHMidt A. R. \& WunderLICH J. 2003. - Sooty moulds from European Tertiary amber, with notes on the systematic position of Rosaria ("Cyanobacteria"). Mycological Research 107: 251-256.

SCHLÜTER T. 1978. - Zur Systematik und Palökologie harzkonservierter Arthropoda einer taphozönose aus dem Cenomanium von N-W Frankreich. Berliner Geowissenchaftliche Abhandlungen (A) 9: 1-150.

SchmidT A. R. \& Dilcher D. L. 2007. - Aquatic organisms as amber inclusions and examples from a modern swamp forest. Proceedings of the National Academy of Sciences of the USA 104: 16581-16585.

SChmidt A. R., Dörfelt H. \& Perrichot V. 2007. Carnivorous fungi from Cretaceous amber. Science 318: 1743.

Vullo R. 2007. — Les vertébrés du Crétacé supérieur des Charentes (Sud-Ouest de la France) : biodiversité, taphonomie, paléoécologie et paléobiogéographie. Mémoires de Géosciences Rennes 125: 1-357.

Submitted on 4 January 2008; accepted on 4 September 2008. 